\title{
IMPROVEMENT OF BEAM TRANSPORT AND TARGET STATION OF TECHNOLOGICAL LINAC "EPOS"
}

\author{
R.N. Dronov, L.V. Reprintsev, V.I. Tatanov \\ National Science Center “Kharkov Institute of Physics and Technology”, Kharkiv, Ukraine \\ E-mail: romandronov@kipt.kharkov.ua
}

To increase the reliability of operation and simplify the precise tuning of the beam it is proposed to upgrade the output part of the accelerator "EPOS" NSC KIPT that operates in the range of electron energies $25 \ldots 35 \mathrm{MeV}$ and beam power up to $12 \mathrm{~kW}$. An additional collimator, beam profile scanner and a wide aperture beam current monitor is offered to install. It is also proposed to upgrade the target station, which will improve the quality of irradiation and improve working conditions for personnel.

PACS: 29.20.Ej, 29.27.-a

\section{INTRODUCTION}

The EPOS accelerator of the NSC KIPT operates in the range of electron energies of $25 \ldots 35 \mathrm{MeV}$ and beam power up to $12 \mathrm{~kW}$ and is currently used for different irradiation programs. Some of radiation technologies require that low energy electrons with energy below $17 \mathrm{MeV}$ must be prevented from getting on the targets which being irradiated. To meet this requirement, the "energy filter" system [1] was installed on this accelerator (Fig. 1).

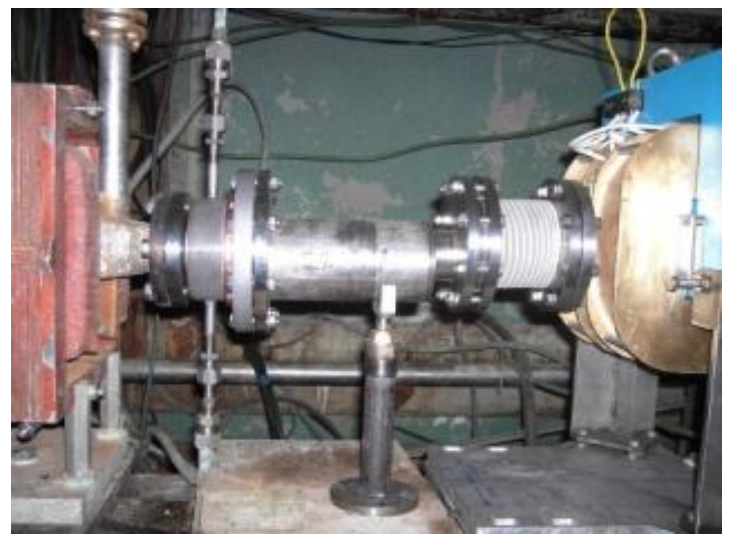

Fig. 1. "Energy filter" system.

Beam travels from right to left

The energy filter consists of dipole magnet [2] with constant magnetic field and collimator. Low-energy electrons were planned to be removed by deflecting it downward with the bending magnet and further dumped on the copper water-cooled Collimator-1 (Fig. 2).

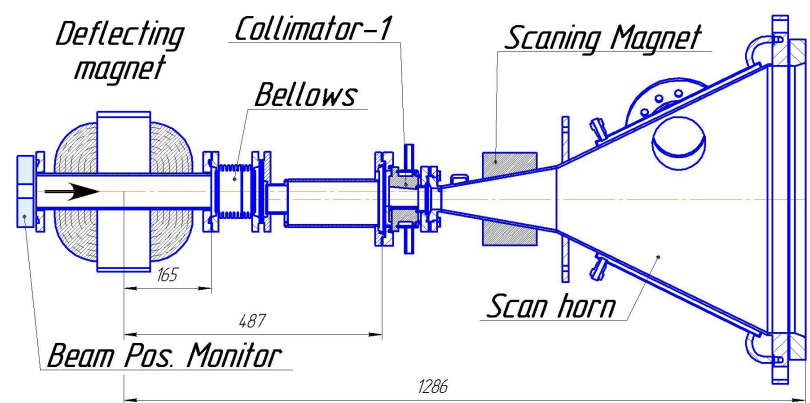

Fig. 2. Output part of "EPOS" accelerator [1]

Nevertheless, in some modes of accelerator's operation, part of the electrons with low-energy hit the walls of linac's drift part and caused vacuum condition to worsen beyond the acceptable operational range. That was the main reason for modernization.

\section{GEOMETRICAL DESCRIPTION OF ELECTRON MOTION}

Trajectories of motion of electrons with different energies were drawn based on equations

$$
\begin{aligned}
& \sin \varphi=\frac{l}{\rho}, \\
& \rho=\frac{10^{4} E(\mathrm{MeV})}{3 H(\mathrm{G})}(\mathrm{cm}), \\
& \frac{l}{2}+\Delta=\frac{l}{1+\cos \varphi},
\end{aligned}
$$

where $E$ - total energy of the accelerated electron; $H$ - induction of magnetic field in the gap of the magnet; $\rho$ - radius of the trajectory of the central particle of the beam in the magnet; $l$ - effective length of the magnet, taking into account the boundary effects; $\varphi-$ angle of inclination at the output, beam input is normal.

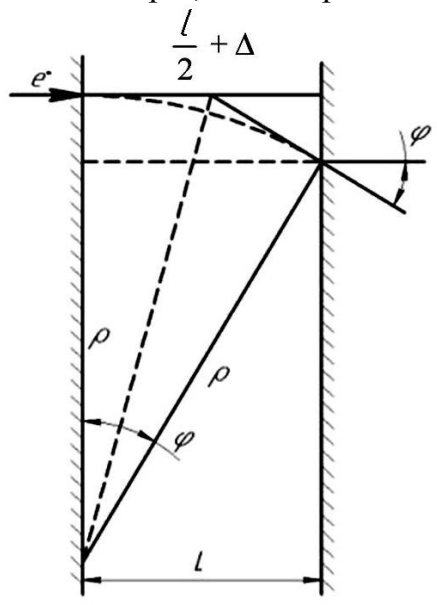

Fig. 3. Scheme of electron passage through a magnet with parallel faces [3]

Because in our case the angle $\varphi<<1$, so when drawing the trajectory of electrons with different energies, it was assumed that they start from the center of the magnet as shown in Fig. 3. As it follows from (3) in the cases when $\varphi<<1$, the distance $\Delta$ between the beginning of geometrical drawing and the center of the magnet is relatively small value: $\Delta: \frac{l}{2} \cong \frac{\varphi^{2}}{4}$.

Table shows the geometric parameters of the trajectory of an electron of nominal energy when passing through a deflecting magnet. 
Parameters of the particles used for calculations

\begin{tabular}{|c|c|c|c|c|c|}
\hline$E, \mathrm{MeV}$ & $H, \mathrm{G}$ & $\rho, \mathrm{cm}$ & $l, \mathrm{~cm}$ & $\varphi, \mathrm{rad}$ & $\varphi, \operatorname{grad}$ \\
\hline 32.5 & 310 & 350 & 13.44 & 0.0384 & 2.2 \\
\hline
\end{tabular}

Fig. 4 shows the output part of the accelerator after the deflecting magnet with possible variants of electron's travel.

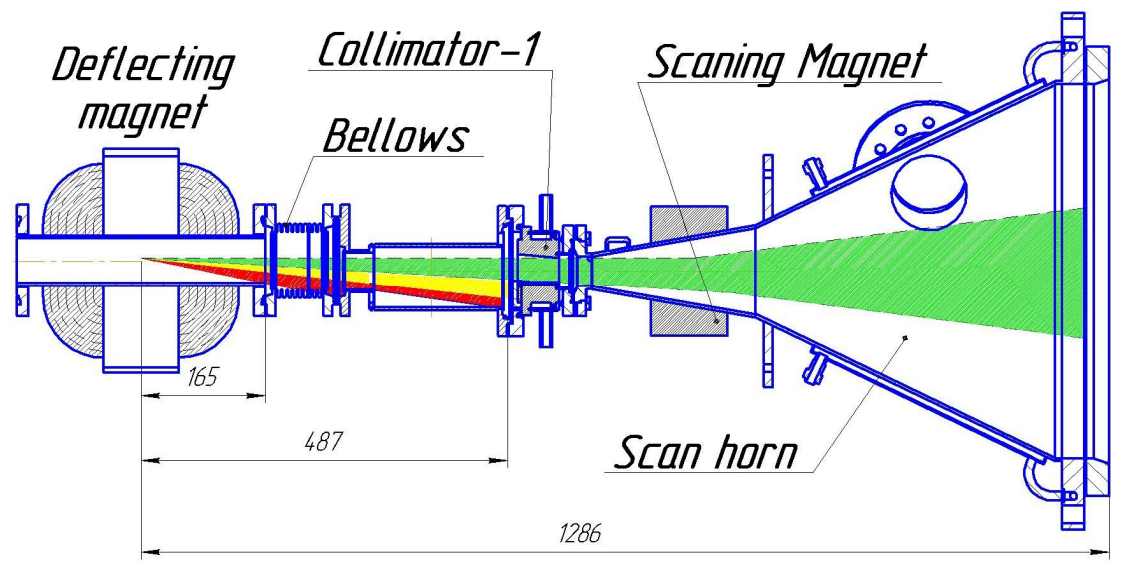

Fig. 4. Scheme of electrons passing through the output part of accelerator

Depending on the energy, the trajectories of electrons are grouped in a three differently colored areas on the scheme that roughly resemble sectors.

The green sector is filled with electron trajectories with energy in the range of $20 \ldots 32 \mathrm{MeV}$. All electrons from the green sector pass freely through the aperture in Collimator- 1 and subsequently hit the target during various irradiation programs.

The electrons moving within the yellow sector have energies in the range of $11 \ldots 20 \mathrm{MeV}$ and fall to the surface of the copper water-cooled Collimator-1. In some modes of accelerator's operation, electrons with energy lower than $11 \mathrm{MeV}$ appear. Possible trajectories of such electrons are located within the red-colored sector. The total power of electrons that appear and move within the red sector and ultimately hit the walls of the vacuum chamber is significant. Power density of the beam is high enough and sufficient to deteriorate the vacuum conditions in the accelerator beyond the operational range and even to damage the drift line completely breaking the vacuum, which already took place in the past.

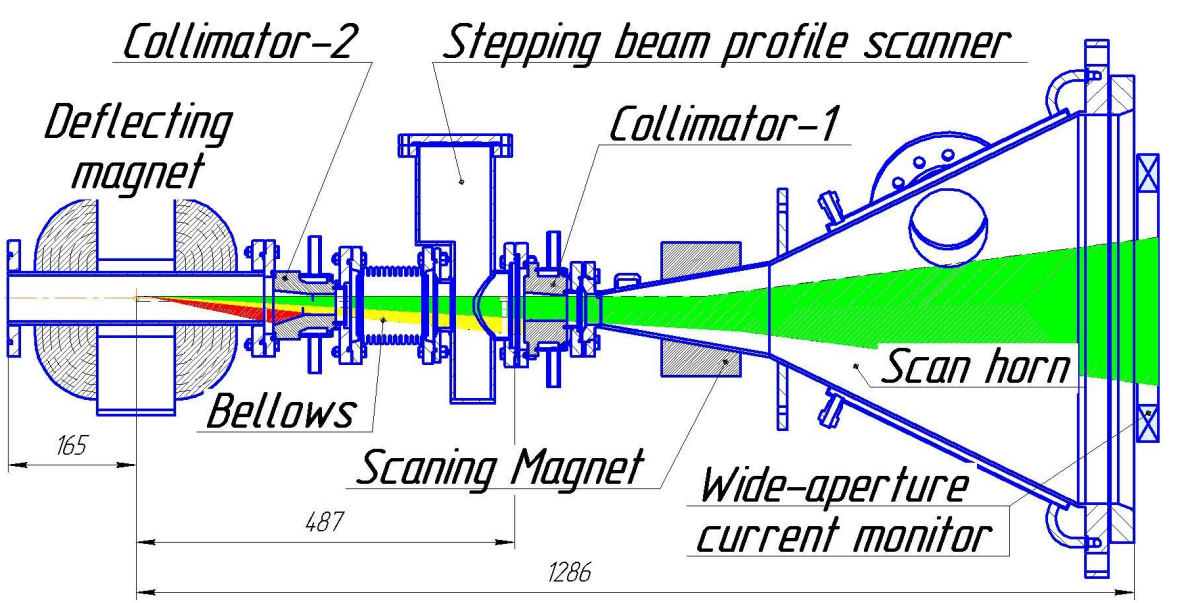

Fig. 5. Proposed configuration of the output part of accelerator

To eliminate the situations in which low-energy electrons hit the wall of the transmission line and deteriorate or break the vacuum, it is suggested to install an additional Collimator-2 (Fig. 5). The Collimator-2 is proposed to be water-cooled with an expanded heat absorption area and decreased electron collision angle up to $25 \ldots 35^{\circ}$.

Fig. 6 shows the proposed Collimator-2 design, existing Collimator- 1 and highlights the difference.
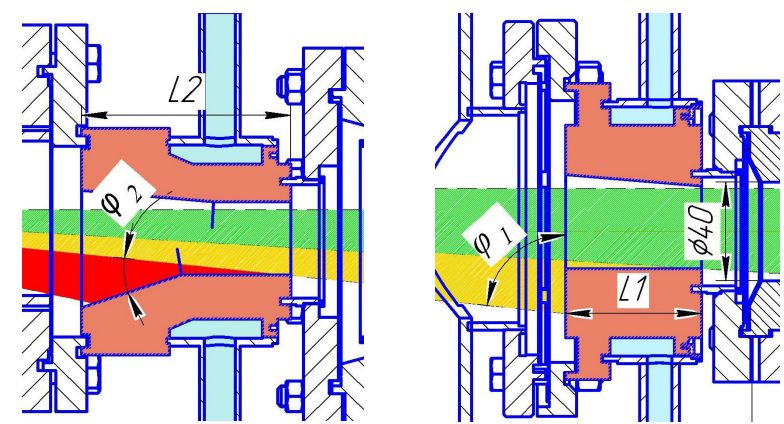

Fig. 6. Comparison of collimator configurations: left - offered Collimator-2 $\left(\varphi_{2}=25^{\circ} ; L_{2}=85 \mathrm{~mm}\right)$; right - existing Collimator $-1\left(\varphi_{1}=85^{\circ} ; L_{1}=55 \mathrm{~mm}\right)$ 


\section{BEAM CURRENT TRAVEL CONTROL}

\subsection{WIDE-APERTURE CURRENT MONITOR OF PULSE ELECTRON BEAM}

At least two current monitors are required to control current through the energy filter channel, which includes a collimator to intercept part of the beam. The current and beam position monitor located at the entrance to the channel (see Fig. 2) controls the parameters of the beam of the "EPOS" accelerator and is an integral part of beam diagnostics system. It is impossible to position the output monitor directly after the oval collimator because of the high radiation load and due to the lack of sufficient space for its installation.
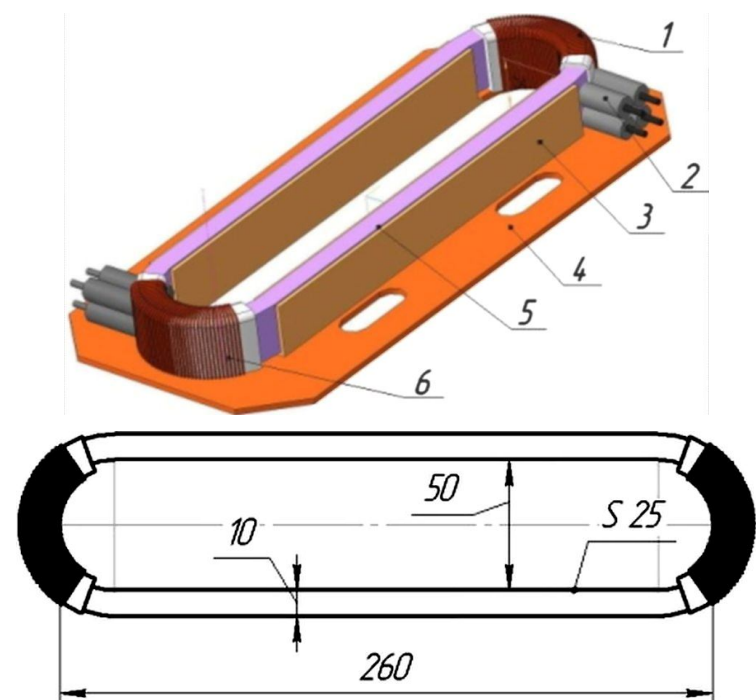

Fig. 7. Wide-aperture current monitor.

Top - simplified monitor design; bottom-dimensions of the core

Therefore, it is suggested to place the output monitor after the vacuum window of the scan horn (see Fig. 5). Vertical size of the part of output window where scanned beam crosses it, is as large as $200 \mathrm{~mm}$, therefore the aperture of the monitor is made $260 \times 50 \mathrm{~mm}(\mathrm{H} \times \mathrm{W})$.

The magneto-induction type monitor (Fig. 7) includes a core (pos. 5) wound with a $100 \mu \mathrm{m}$ thick permalloy ribbon. Structurally, it is embedded in an aluminum clamp (pos. 3) and secured to the plate (pos. 4). The latter is attached to the outlet flange of the scan horn. Two windings (pos. $1 ; 6$ ), together with the calibration coils, are located on the end portions of the core and insulated with a fiberglass tape. Terminals are made using special ceramic insulators (pos. 2).

Main parameters of a monitor:

- Number of coils: $\mathrm{W}=100$; inductance $\mathrm{L}=50 \mathrm{mH}$; specific capacity of each winding $\mathrm{C}=200 \mathrm{pF}$.

- Core cross section $\mathrm{S}=2.5 \mathrm{~cm}^{2}$; length of magnetic force line $1=65 \mathrm{~cm}$.

- Aperture $(\mathrm{H} \times \mathrm{W}) 260 \times 50 \mathrm{~mm}$; overall dimensions: $280 \times 75 \mathrm{~mm}$.

- Pulse tilt: $\Delta \mathrm{U} / \mathrm{U} \leq 1 \%$ with $100 \Omega$ termination and pulse duration $\tau=3.5 \mu \mathrm{s}$; raise time: $\tau_{\mathrm{e}} \leq 50 \mathrm{~ns}$.

- Magnetic permeability of the core: $\mu=10^{4}$.

- Beam current monitor response: $\mathrm{U} / \mathrm{I}=1 \mathrm{~V} / \mathrm{A}$.

The signals from both windings are fed to the ADC inputs and processed by the computer. The sum of the signals gives the value of the beam current in the pulse. The difference of the signals divided by their sum gives the instantaneous position of the beam's center and the sweep deflection angle. In this way, energy control and beam interlocking can be performed without scanning.

\subsection{INNER BEAM PROFILE STEPPING SCANNER}

To control the profile of a beam in front of the oval outlet Collimator-1 (see Fig. 5), an internal beam profile stepping scanner is planned to be installed. This scanner is a modification of the previously developed scanner [4] shown in Fig. 8.

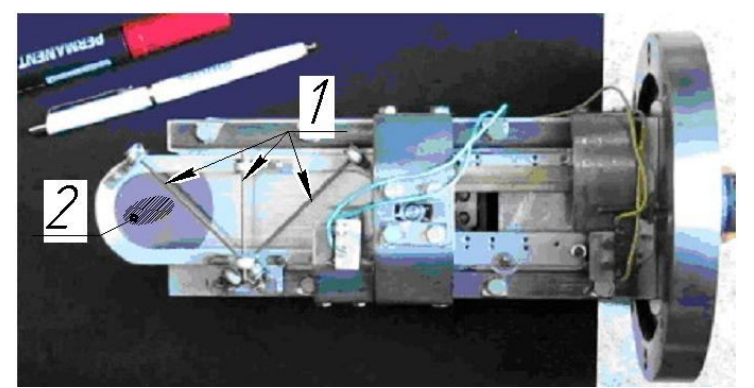

Fig. 8. Prototype Inner Beam Profile Stepping Scanner

The moving frame of prototype scanner contains three differently oriented tubular probes (pos. 1) with $45^{\circ}$ angular spacingf between them. Such probe arrangement was initially used to scan the profile of an ellipse-shaped beam (pos. 2) with ellipse axes tilted to the horizon.

Specifications of prototype scanner:

Probe travel

$82.5 \mathrm{~mm}$

Number of steps per full travel $\quad 175$

Step rate

Linear step of probe's movement

Duration of three measurements

Probe speed

Linear backlash of a probe

Aperture

Probe material

Probe diameter

$25 \mathrm{~s}^{-1}$

$0.47 \mathrm{~mm}$

$7 \mathrm{~s}$

$12 \mathrm{~mm} / \mathrm{s}$

$0.25 \mathrm{~mm}$

$30 \mathrm{~mm}$

$\mathrm{Ni}$

$1.5 \mathrm{~mm}$

The thickness of the probe's wall $\quad 50 \mu \mathrm{m}$

Permissible probe temperature $\quad 800^{\circ} \mathrm{C}$

Max. operating temperature $\quad 500^{\circ} \mathrm{C}$

Cooling time $\left(500 \ldots 200^{\circ} \mathrm{C}\right) \quad 20 \mathrm{~s}$

Max. output signal $\left(\mathrm{R}_{\mathrm{L}}=75 \Omega\right) \quad 225 \mathrm{mV}$

Number of probes

3

Parameters of the beam used in the calculations:

Beam current $0.6 \mathrm{~A}$

Beam pulse duration $\quad 4 \mu \mathrm{s}$

Pulse repetition rate $\quad 100 \mathrm{~Hz}$

Conditional beam diameter $\quad 7.5 \mathrm{~mm}$.

The inner beam profile stepping scanner is intended for scanning the beam core profile and measuring full charge of the deflected beam. Unlike prototype scanner [4], the new inner beam stepping scanner will use a modified moving frame that is shown in Fig. 9. This moving frame contains two different probes. The planar probe (pos. 1) is made of titanium plate $(50 \mu \mathrm{m}$ thick) and tubular one (pos. 2) is nickel tube $1.5 \mathrm{~mm}$ in diameter with $50 \mu \mathrm{m}$ wall thickness. Delta-electrons from these two probes form the scanner's signal. 


\section{Plate probe $40 \times 40 \times 0,05 \mathrm{~mm}$}

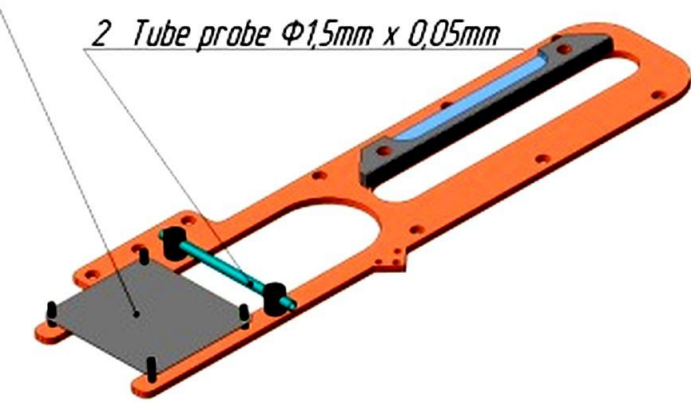

Fig. 9. Technical drawing of moving frame of inner beam stepping scanner with planar and tubular probes

Carbon rod $0.5 \mathrm{~mm}$ in diameter may be used as a possible substitute for tubular probe made of nickel and further development and testing of this option is underway.

\section{LOW ACTIVATION TARGET STATION}

The target station, which presently installed at "EPOS" linac is intended for irradiation of different bulk materials with scanned electron beam. Materials to be irradiated are usually placed in series of specially designed cartridges. To avoid overheating of the samples during irradiation, water spraying is used.

The distribution of scanned electrons on the target is non-uniform; this leads to the necessity of shifting the cartridges periodically in course of irradiation. The set of total six vertical cartridges (similar to those shown in Fig. 11) is divided into two parts. Left and right parts with three cartridges in each then shift horizontally to take each other's place to compensate for uneven electron irradiation. At present the shifting is performed manually, which results in increased processing time.

To improve both the working conditions and the quality of the irradiation procedure, a new target station (Fig. 10) is proposed as the second stage of reconstruction.

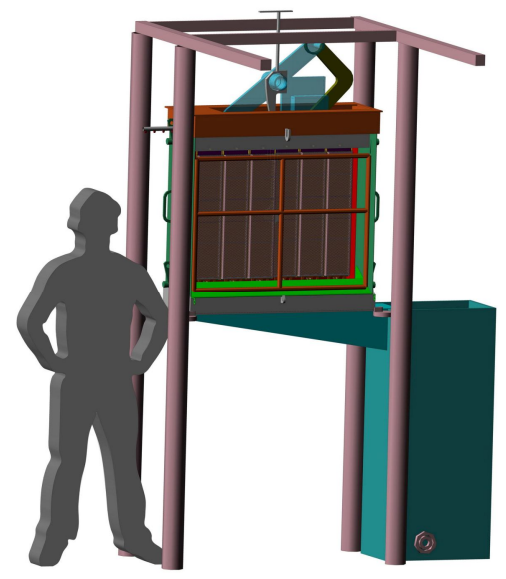

Fig. 10. Target station with front cover removed

Newly developed target station features cartridge shifting device (see Fig. 11) which remotely shifts the cartridges in mid run, thus saving time and reducing operational costs. Shifting is performed by alternated 90 degrees turn of hinged cartridge holder with the counterweight. The result of shifting is seen in Fig. 11 with all cartridges numbered. Remote cartridge shifting reduces personnel exposure and shortens the time needed for radiation treatment.
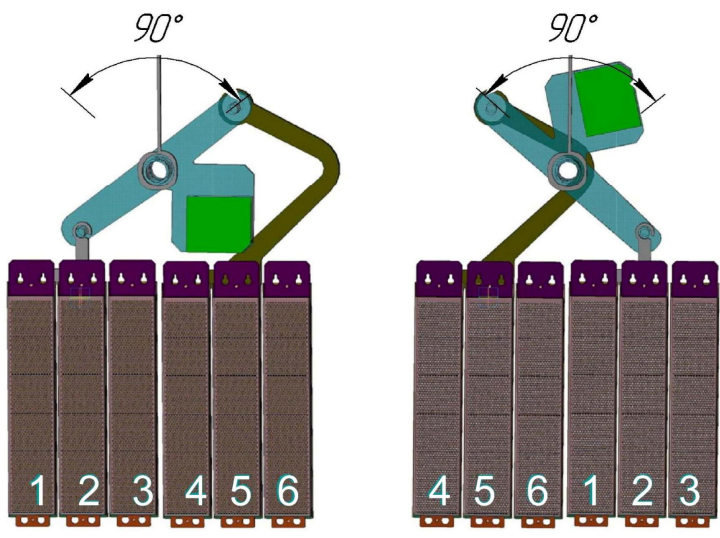

Fig. 11. Six cartridges mounted on remotely operated hinged holder:

left - initial position; right - shifted position

An aluminum alloy AD31 will be the main structural material for manufacturing this target station. As described in [5], this aluminum alloy is more attractive in terms of induced activation level comparing to previously used duralumin and stainless steel, which improve personnel safety too.

\section{CONCLUSIONS}

1. The proposed modification of the output part of the "EPOS" accelerator allows eliminating the disadvantages of the "energy filter" system such as vacuum deterioration or even breaking and radiation contamination of equipment. Installing a step scanner will allow us to control the low energy "tail" of the energy spectrum, making tuning of accelerator easier.

2. Installation of a wide-aperture current monitor will guarantee continuous operational measurement of beam current and instantaneous position of the beam immediately after the vacuum window. This will allow us to monitor the sweep angle and the energy of the electrons and instantly interlock the beam if these parameters fall outside the operational range.

3. Usage of developed target station will shorten treatment time, reduce operational costs and improve personnel safety.

\section{ACKNOWLEDGEMENT}

We are profoundly grateful to the late Leonid M'yakushko for very useful advices and encouragement during the early stage of this work.

\section{REFERENCES}

1. V.N. Boriskin, I.S. Guk, A.N. Dovbnya, et al. Energy filter system for the accelerator "EPOS" // Problems of Atomic Science and Technology. Series "Nuclear Physics Investigations”. 2012, № 3, p. 39-43.

2. I.S. Guk, A.N. Dovbnja, S.G. Kononenko, et al. The dipole magnet of the energy filter for accelerator "EPOS"// Problems of Atomic Science and Technology. Series "Nuclear Physics Investigations". 2012, № 3, p. 67-69.

3. A. Bendford. Transportirovka puchkov zaryazhennyx chastic. M.: “Atomizdat”, 1969 (in Russian). 
4. R.N. Dronov, L.K. Myakushko, L.V. Reprintsev, V.A. Shendrik. A stepping scanner of internal beam profile of the technological electron linac // Book of abstracts XIX International Workshop on Charged Particle Accelerators. Sept. 12-18, 2005, Ukraine, p. 89.
5. Ye.Z. Biller, R.N. Dronov, V.F. Zhiglo. Low activation target handling station for photonuclear isotope production on electron linac // Book of abstracts XXIII International Workshop on Charged Particle Accelerators. Sept. 8-14, 2013, Ukraine, p. 160-161.

Article received 24.01.2020

\section{УСОВЕРШЕНСТВОВАНИЕ ТРАКТА ПРОВОДКИ ПУЧКА И МИШЕННОГО КОМПЛЕКСА ТЕХНОЛОГИЧЕСКОГО ЛУЭ “ЭПОС“}

\section{Р.Н. Дронов, Л.В. Репринцев, В.И. Татанов}

Для повышения надёжности работы и упрощения точной проводки пучка предлагается модернизировать выходной тракт ускорителя “ЭПОС“ ННЦ ХФТИ, который работает в диапазоне энергий электронов $25 \ldots 35$ МэВ и мощности пучка до 12 кВт. Предлагается установка дополнительного коллиматора, сканера профиля пучка и широкоапертурного монитора тока пучка. Также предлагается модернизировать мишенные устройства, что повысит качество облучения и улучшит условия работы персонала.

\section{ВДОСКОНАЛЕННЯ ТРАКТУ ПРОВОДКИ ПУЧКУ І МШШЕНЕВОГО КОМПЛЕКСУ ТЕХНОЛОГІЧНОГО ЛПЕ "ЕПОС"}

\section{Р.М. Дронов, Л.В. Репринцев, В.І. Татанов}

Для підвищення надійності роботи і спрощення точного проведення пучка пропонується модернізувати вихідну частину прискорювача “ЕПОС“ ННЦ ХФТІ, що працює в діапазоні енергій електронів 25...35 МеВ і потужності пучка до 12 кВт. Пропонується установка додаткового коліматора, сканера профілю пучка та широкоапертурного монітора струму пучка. Також пропонується модернізувати мішеневі пристрої, що підвищить якість опромінювання і поліпшить умови роботи персоналу. 